\title{
University classroom interactive situation microanalysis: cognitive attunement and pedagogical interpretation
}

Calduch, Isaac ${ }^{\mathrm{a}}$; Hervás, Gabriel ${ }^{\mathrm{a}}$; Jarauta, Beatriz ${ }^{\mathrm{a}}$ and Medina, José Luis. ${ }^{\text {a }}$

${ }^{\mathrm{a} D e p a r t m e n t}$ of Teaching and Learning and Educational Organization, University of Barcelona, Spain.

\begin{abstract}
This conference paper aims to elucidate the attuning processes between teacher knowledge and the learning moment of the students, in interactive situations within the university classroom, under a situated perspective and in real-time; specifically, in relation to the process of didactical interpretation. An episode performed by an expert teacher is analyzed; it took place in the Clinical Nursing subject of the nursing degree and was about the use of the physiological serum in certain situations. The analysis focuses on the interaction between the teacher and the students, adopting a research methodology close to the ethnography of communication -in its microethnographic aspect-, adopting the sequence $S-T-S^{\prime}$ (student-teacherstudent) as the unit of analysis. The results show how the teacher has the ability to evaluate the appropriateness of the students' interventions in situ, thanks to which she is able to adjust her response (dynamic coupling), generating a pedagogic resonance. Concurrently, it can also be seen how, beyond tuning in with a particular student, she manages to tune in with the rest of the class (collective attunement).
\end{abstract}

Keywords: Higher education; Attunement; Didactic interpretation; Microanalysis. 


\section{Introduction}

By implementing the guidelines of the European Higher Education Area (EHEA), the universities reformulated their degrees, but this was not always matched with a transformation of the teaching culture, an essential process to achieve a more studentcentred teaching.

If we accept that the nature of teacher's knowledge is indissoluble from professional practice (Tardif, 2004; Medina, 2013), its analysis requires considering: 1) a situated approach; 2) to focus on the articulation and deployment mechanisms, considering their procedural nature; 3) to incorporate the students' perspectives without neglecting the interaction layout.

Approaching an investigation from this position is aligned with the framework of the EHEA and is consistent with the social-constructivist learning theories. For this, it is important to focus on the situated characteristics of articulation and coupling processes between the teacher knowledge, the learning moment of their students and the specific teaching-learning situations. This makes essential to pay attention to the dynamic of these processes, especially the intersubjective component between the teacher and his/her students.

As an antecedent, it is appropriate to mention the study of Medina, Cruz and Jarauta (2016), which highlights how some well-valued teachers use different strategies to tune their action to the specific needs of their students due to a coordinated use of their disciplinary and pedagogical knowledge. In summary, the authors found that these teachers used the Pedagogical Content Knowledge (PCK) identified by Shulman (1987). But, beyond that, in their study, they identified a less studied feature of the PCK, its reflexive-dialogic dimension, which allows teachers to focus their attention floatingly on both the ideas expressed by the students and in their own understanding frameworks; thanks to that, the processes of knowledge transformation, or of didactic transposition (Chevallard, 1997), and the other teacher skills acquire a new more relational meaning.

The purpose of this paper is, precisely, to give light to a research that seeks to understand how university professors interpret, evaluate and respond to the studens' contributions -into a structure of discursive interactions- and their repercussions in terms of learning. This is done taking into account the processes of cognitive tuning between both (which occur as a result of a didactic interpretation, made by the teacher) and with the ultimate aim of considering the results obtained to be used in further training and professional development processes that ensure the implementation of pedagogical innovations and teacher improvement actions. 


\section{Context}

The research presented here has been developed in the nursing degree at the University of Barcelona, during the 2016-2017 academic year. Specifically, it is analysed a session of the compulsory subject of Clinical Nursing II, within the thematic block "General aspects of critical patient care".

\section{Methodology}

Interested in how the teacher interprets, evaluates and respond to the students' contributions, and its repercussions in terms of learning, we take an onto-epistemological perspective close to the Symbolic Interactionism (Blummer, 1969), considering the importance of meaning construction during interaction.

The methodological specification of the previous statement, leads us to the development of an Ethnography of Communication (Hymes, 1962) in the form of a microethnography. Through it, we intend to analyze the interaction (as a communicative event), at every instant, to comprehend the meanings that the protagonists give to their words and actions, paying attention to linguistic, sociocultural and cognitive factors, both at an intersubjective and intra-subjective level.

The unit of analysis for this study corresponds to the sequence S-T-S' (studentteacherstudent), differentiating three interrelated processes in the moment that corresponds to the teacher ( $\mathrm{T})$ : identification, evaluation and answer.

The methodological process of the research can be summarized in the following phases:

1) Non-participant observation of the classroom and its recording;

2) Edition and analysis of the video recorded to select S-T-S' sequences;

3) Recorded think aloud interview (Erickson and Simon, 1993) -to teachers and students- to allow the participants explicitly state the meaning and intentionality of their actions and speeches occurred in the preselected sequences;

4) Parallel transcriptions (Weston and McAlpine, 2002) of the previous phases, useful to gather and analyse concurrent data about a shared experienced and its dynamicity;

5) Micro-analysis, focused on the thinking and the action of the teacher;

6) Holistic analysis (relational, contextualized and triangulated with the protagonists and specialists). 


\section{Results}

The creation of edited videos focused on the analysis unit previously mentioned, and the subsequent interpretation of the selected micro-events, allow for evincing coupling and attuning cognitive processes occurred in real time in the classroom.

Table 1, created following the parallel transcriptions technique (Weston and McAlpine, 2002), shows one of those micro-events, chronologically sequenced and maintaining the focus of attention in the classroom situation, and the reflection of the students and the teacher.

The events developed belong to a moment of the class about the types of serum that could be used in a pressurizer. Previously, the teacher explained the use of different types of catheters and serums and, after it, she formulates a question and "Student 1" responds with a doubt that connects it with her previous understanding of the contents. That's the event where the transcription starts. There, it can be found how both "Student 1" and the teacher reflect on the motivations to ask, the interpretation of the question and, simultaneously, how that moment is understood by "Student 2", leading him to ask another question that, again, is assessed by the teacher.

Table 1. Microevent: Pressurizing serum (moment 1 \& 2)

\begin{tabular}{|l|l|l|}
\hline Teacher & \multicolumn{1}{|c|}{$\begin{array}{c}\text { Situation } \\
\text { (Classroom event) }\end{array}$} & \multicolumn{1}{|c|}{ Students } \\
\hline & $\begin{array}{l}\text { Teacher: What type of } \\
\text { serum will you put in the } \\
\text { pressurizer? }\end{array}$ & $\begin{array}{l}\text { Student 1: But if you said it } \\
\text { was not a regulated, I } \\
\text { understood a physio 0.9 } \\
\text { [physiological saline } \\
0.9 \% \text { ]. } \\
\text { Teacher: Why? Because } \\
\text { it's not a regulated one? }\end{array}$ \\
\hline & $\begin{array}{l}\text { Why are you making that } \\
\text { comment? } \\
\text { Student 1: Yes, because in a } \\
\text { previous class she had }\end{array}$ \\
\hline
\end{tabular}




\begin{tabular}{|c|c|c|}
\hline & & $\begin{array}{l}\text { explained we have to } \\
\text { administer a physiological } \\
\text { saline solution. So I was } \\
\text { surprised by the comment } \\
\text { she made after that we can } \\
\text { also use a dextrose one. }\end{array}$ \\
\hline \multirow[t]{4}{*}{$\begin{array}{l}\text { What did you think when } \\
\text { you heard her? } \\
\text { Teacher: I love the } \\
\text { 'because you said it'. When } \\
\text { the students tell me } \\
\text { 'because you said it', I } \\
\text { know they are thinking 'this } \\
\text { is so because you said it'. } \\
\text { And I do not want that. } \\
\text { Teacher: In addition, I } \\
\text { thought that, like her, half } \\
\text { of the class was thinking } \\
\text { the same: "If you have said } \\
\text { no before, why do you say } \\
\text { yes now?" }\end{array}$} & & \\
\hline & & $\begin{array}{l}\text { Do other students think the } \\
\text { same? } \\
\text { Student 2: It was a question } \\
\text { that I was also asking } \\
\text { myself. }\end{array}$ \\
\hline & $\begin{array}{l}\text { Student 2: But if, for } \\
\text { example, he is a } \\
\text { hepatopathist ... you will } \\
\text { not put the physio, right? }\end{array}$ & \\
\hline & & $\begin{array}{l}\text { Why are you asking this } \\
\text { question? } \\
\text { Student 2: I had this doubt. } \\
\text { I did not fully understand } \\
\text { what a not regulated serum } \\
\text { is. }\end{array}$ \\
\hline
\end{tabular}




What did you think when
you heard him?
Teacher: When I heard
him, I thought... 'Oh, you
have understood me, you
have understood me.... I
mean, I realized that he was
thinking... he was
reasoning, and doing it
well. What he says is
correct. We could put a 5\%
dextrose... if it did not have
the issue to stick. It is water
with sugar and... $\quad$

\section{Discussion}

The analysis of these micro-events during the class sessions, allows to reflect on the objective we set at the beginning, related with understanding the possible moments when cognitive attuning between the thinking of the teacher (and her knowledge) and the students' (and their learning) happens.

Focusing the attention in the answer of the teacher when she is asked about what she was thinking when both students asked, we can observe:

1) The comprehension and assessment (in situ) of the appropriateness of the intervention, connecting and recognizing the mental process of the student in respect to the disciplinary content: "I mean, I realized that he was thinking... he was reasoning, and doing it well".

2) The attunement with the thinking of the rest of students in the class, via the specific component of the PCK that refers to the knowledge of how a specific content is usually understood and the difficulties linked to its learning: "I thought that, like her, the half of the class was thinking the same thing".

Both, can be considered as part of the cognitive process of dynamic coupling (Medina and Jarauta, 2013); constitutive element of the dialogical-reflective dimension previously referred to. The teacher makes a diagnosis of the learning situation where the student and the class are situated, and that allows her to adopt her teaching action -in real time- 
generating pedagogic resonance (Trigwell and Shale, 2004) as she adjusts her following interventions.

\section{References}

Blumer, H. (1969). Symbolic Interaction: Perspective and Method. Englewood Cliffs: Prentice Hall.

Chevallard, Y. (1997). La transposición didáctica. Del saber sabio al saber enseñado. Buenos Aires: Aique.

Ericksson, K.A. \& Simon, H.A. (1993). Protocol Analysis. Verbal Reports as Data. Cambridge: The MIT Press.

Hymes, D. (1962). The Ethnography of Speaking. En T. Gladwin y W.C. Sturtevant (Eds.), Anthropology and Human Behavior, pp. 13 -53. Washington: Anthropology Society of Washington.

Medina, J.L.; Cruz, L. \& Jarauta, B. (2016). La dimensión dialógico-reflexiva del conocimiento didáctico del contenido en la docencia universitaria. Revista de Educación, 274, 69-93.

Medina, J. L. (2013) Una reconceptualización de los saberes profesionales que se enseñan en la universidad: más allá de las competencias. In J.L. Medina y B. Jarauta, Enseñanza y aprendizaje en la educación superior, pp. 35-84. Madrid: Síntesis.

Shulman, L. (1987). Knowledge and teaching: foundations of the New Reform. Harvard Educational Review, 57(1), 1-22

Tardif, M. (2004). Los saberes del docente y su desarrollo profesional. Madrid: Narcea.

Weston, C. \& McAlpine, L. (2002). Parallel transcripts: an innovative approach for capturing the impact of reflective teaching on student learning experience. New Orleans: Annual Meeting of the American Educational Research Association. 